even, I think, Ducks Unlimited fancies itself in favor of animal rights. And perhaps the leaders of these organizations think of thenselves that way, too. What has happened is this. There is or was so much bombast on the part of those who proclaimed a "land ethic" that it was almost inevitable that there would be unrealized implications of precisely the sort that trained analytic philosophers with pro-animal sentiments were bound to take exception to. More sophisticated philosophers with pro-land ethic sentiments, like Rodman, leaped into the fray and, so far as I can tell, have extended their commitment to ecoholism beyond the wildest dreams of their original mentors. In any case, so I see it.

It is Finsen's merit that she has done her very best to salvage the views of people like Rodman by showing that they want much the same sorts of things that animal rights proponents do. Unhappily, the deck was stacked against her because--and I hope the reader won't find it outrageous that I put this so baldly--it is trivially true that sentient life has value independent of its role in any ecosystem, and it is also true, although perhaps not trivially, that an ecosystem has no value that could ever supersede the value of the totality of sentient life. (This is not to say that deep ecology is false. Ecosystems may have their own, but lesser, value independent of the value of sentient beings.) Ecoholism, when not ariven to extravagant limits, has much in it to be adnired. When it conflicts with a concern for life, it is patently absurd. The best reconciliation would be for the ecoholists to admit this.

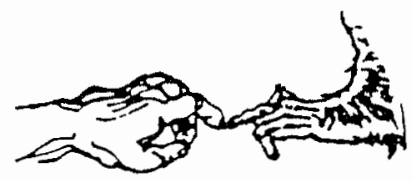

Notes

1. Robert Loftin, "The Medical Treatment of Wild Animals," Environmental Ethics (Fall, 1985).

2. J. Baird Callicott, in Environmental Ethics (Winter, 1985).

3. R. Will Flowers, "Ethics and the Hypermodern Species," Environmental Ethics (Surmer, 1986).

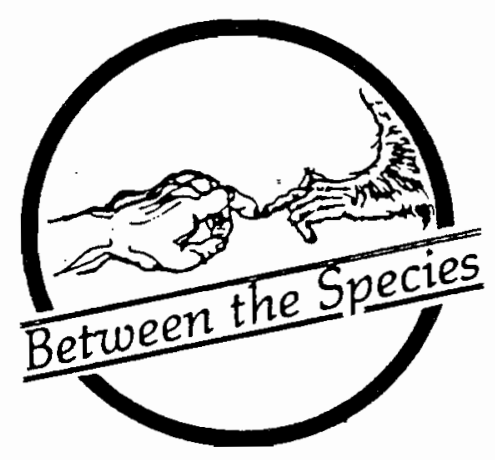

DOMBROWSKI ON

INDIVIDUALS, SPECIES,

AND ECOSYSTEMS

At the end of his excellent historical study, The Philosophy of Vegetarianism, Daniel Dombrowski suggests that "perhaps the most sophisticated version" of "a world of nature alive" "is found in the recent thought of Charles Hartshorne.[1]" The present paper develops such an Harshornian metaphysics and applies it to the moral status of individuals and species.

According to Dombrowski, animals, including humans, are individuals made up of living cells. Lacking the integration of a nervous system, plants are individuals in a much weaker sense. A mere colony of cells, "each for the most part on their own," plants also lack the psychological individuality of animals, Sentiency 2, the ability to feel pain. But lower-level feelings or experiences, Sentiency 1, exist in plants, rocks, and throughout nature at the microscopic level.

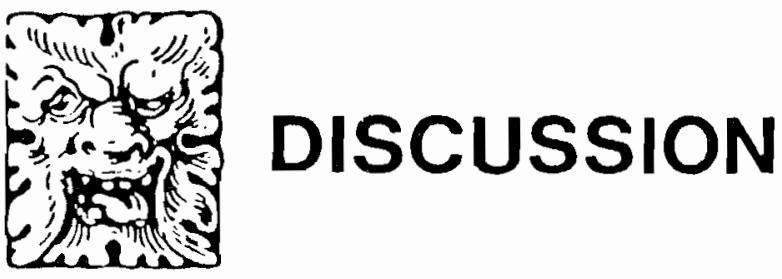


We know that the world is made up of concrete feelings by analogy with human nature, which we inevitably must use to interpret nonhuman nature. Since our pain is localized in our cells, we have direct evidence that our cells feel and hence that animals with cells and nervous systems like ours also feel.

Having laid out this metaphysical framework, Dombrowski applies it to some moral perplexities involving individuals and species. Besides higher-grade sentience, individual animals have internal relations to other individuals. Duties are owed to individuals because they can suffer and because they possess dignity. Thus, unnecessary killing of individual animals is morally wrong, and exclusive concern with species and ecosystems is callous.

Though we owe duties primarily to individual animals, there are two reasons why we do not owe duties only to them. First, human beings should preserve animal species since diversity of species is beautiful. Aesthetic considerations trump economic considerations

and are central to life lived on a high level. Second, on the hypothesis that there is a superhuman individual who experiences the whole of things, this all-inclusive value is diminished by the reduction of diversity through extinction of species and by the existence of unnecessary pain and premature death of individuals. Human actions contribute good and evil to the divine nature, because God is the actual, concrete whole of which we and the rest of nature are parts. our ultimate obligation is to contribute value to the whole of things, including the value of individual animals, both human and nonhuman.

This position has an undeniable appeal. First, Dombrowski situates some crucial but isolated analytic arguments for animal rights in a more comprehensive metaphysical framework. For example, how do we know that animals experience pain, that the notorious Cartesian view of animal automata is false? We argue analogically and correctly point out that both animal and human pain are known by analogy with ourselves, an analogy equally strong in each case. Dombrowski makes this point more general: we must understand the world outside our experience by analogy with our experience. This claim, which leads quite naturally to panpsychism, both strengthens and is strengthened by the human/animal analogy common in the animal rights literature.

Second, Dombrowski rightly laments the philosophical and practical disaster area called "metaphysical dualism." But most proposed alternatives to dualism have been materialist. Whatever the philosophical defects of panpsychism--and I will shortly mention a few--proponents of materialist monisms do risk encouraging environmental exploitation by restricting subjective experience and moral value to animals alone.

Third, Dombrowski offers the prospect of a partial reconciliation between the animal rights and environmental ethics positions. Advocates of the former wonder how we can owe direct duties to something unless it can experience being harmed or benefited, while advocates of the latter proclaim that maintaining the integrity and stability of the biotic community has intrinsic or inherent

value. Dombrowski's panpsychism narrows the gap between these positions by extending lowgrade Sentiency 1 throughout the world. Plants and rocks have value because they can feel, which extends value throughout creation while maintaining the requirement that moral patients must be conscious. Without some move such as this, we may be condemned to hearing the advocates of animal rights . and environmental ethics argue without resolution well into the next century.

Finally, a more general argument may be made for process metaphysics. The explanatory role of entities in science, Dombrowski hints, plays a crucial role in determining what is metaphysically individual and what is metaphysically a conposite. "Botanists explain growth in plants through cells, not nervous systems." Most philosophers today would indeed agree that an acceptable metaphysics must be compatible with the best advailable science, because there is no sharp, ultimate line between science and metaphysics.

Historically, process philosophy came about as an improved empiricism. In the early part of this century, Alfred North Whitehead's process philosophy combined Leibniz and Einstein. Newtonian physics had postulated hard, impenetrable, dead particles 
as ultimates, and the antique, atomistic empiricisms of Iocke and Hume developed on this assumption. But post-Einsteinian physics and Whiteheadian metaphysics favor fields of forces. These theories incorporate the importance of perspective. A more unified empiricism, continuous and consistent with contemporary science, must remain the goal of any contemporary metaphysics able to claim our intellectual allegiance.

Dombrowski's project has far to go to satisfy this goal, however.[2] Unfortunately, he follows Hartshorne in developing process metaphysics backwards into neo-platonic rationalism instead of forwards into a view integrated with relevant contemporary science. The fundamental questions here are these: How big are the actual entities, the concrete occasions Dombrowski is speaking about? How do they connect with the entities discussed by the relevant sciences? At times he says they are living cells; at other times

he says they are much smaller, existing at the subatomic level. He cannot have it both ways, but choosing either alternative would force him to modify his moral position.

Suppose actual entities are much smaller than cells. If we locate actual occasions and ultimate individuality down at or beneath the level of the entities discussed in contemporary physics, which I believe is whitehead's view, the crucial analogy between our experience and the experience of actual occasions is very much weakened. Furthermore, in this case the role of the nerve cells in experience is not metaphysically ultimate, since these cells themselves are composites. To call a cell an actual occasion if it is really a composite of actual occasions is to commit the dreaded "fallacy of misplaced concreteness." The upshot is that the metaphysical distinction betwren Sentiency 1 and Sentiency 2 collapses, and along with it collapses the moral distinction Dombrowski wants to make between individual animals and the rest of nature.

Suppose, on the other hand, that actual entities are nerve cells. This seems to be the dominant view in Dombrowski's paper. It would follow that whatever is composed of units smaller than nerve cells will be a part of an actual occasion, not an actual occasion. Attributing features of an individual to its parts is the fallacy of division. In this case, rocks and trees do not feel and have experiences, since nerve cells are the smallest things that feel, and rocks and trees do not contain nerve cells. Hence, on this alternative, the attempt to attribute Sentiency 1 to them fails, and with this failure Dombrowski is back to the dualist view that plants and ecosystems are not direct subjects of experience, nor, presumably, of our moral concern.

An equally complex nest of issues concerns the nature and role of aesthetic value. Following Hartshorne, Dombrowski limits our aesthetic concern with nature to delight in its diversity. But this again seens to be an inadequate, neo-classical rationalism. For one thing, humans will soon be able to produce species at will via genetic engineering. Should we create lots of genetic oddities to increase diversity and make up for prior

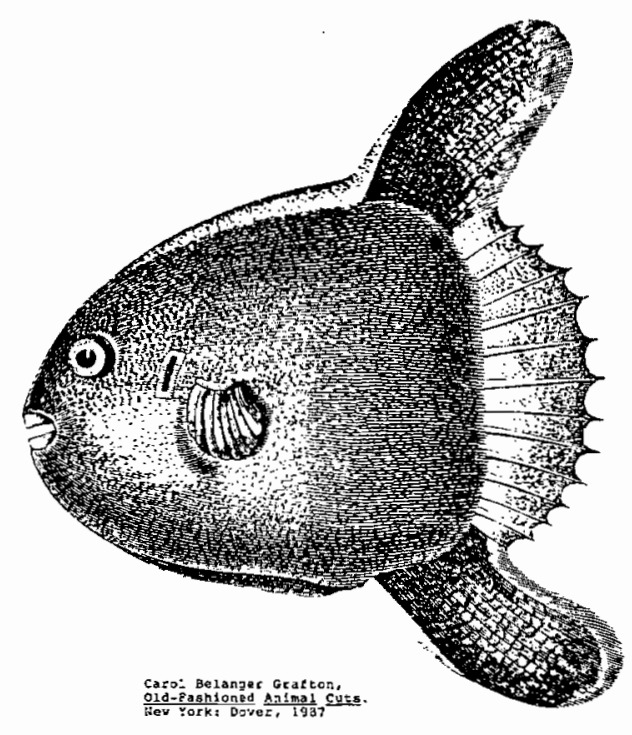

extinctions? Second, the aesthetic argument fails to help much when there are trade-offs between natural beauty and beautiful artifacts. A lot of forests have been cleared, and individual animals living in them extinguished, to create Fnglish gardens, Italian violins, and the paper for books published by university presses. If the beauty of such products is greater than what is lost, what does the aesthetic argument recommend?

Another problem concerns Dombrowski's 
exclusive focus on suffering, a view seriously incomplete when applied to ecosystens and wilderness. Sympathy for suffering is a fundamental moral attitude, as both Buddhism and Humean ethics agree. Personally, I doubt if reading Animal Liberation all by itself would have led me to become a vegetarian. Soon after reading singer I paid several visits to the primate house at the Lincoln Park Zoo in Chicago. As I watched, feelings of pity and injustice gradually overtook me. The turning point may have come the day I read the plaque on the front of the primate house: Ray Kroc, founder of McDonald's, paid for the place! Both my head and my heart had to change before I could abandon eating meat.

But such experiences of sameness should not blind us to experiences of otherness. Two summers ago, I went backpacking in Isle Royale National Park, where I was nearly charged by a cow moose busy leading her two calves up the shoreline of Lake Superior. I am glad to have seen her, though I certainly did not feel pity and oneness with her at the time. What I felt was fear. Encountering that moose, and similar encounters I've had with a bear and a copperhead, led me to respect them, not pity them. The experience of continuity between ourselves and the rest of nature gives rise to compassion for animal pain as a basic moral attitude. But the experience of otherness, though less frequent, may be just as fundamental.

The value of wilderness ecosystems for us is connected with their otherness, with their scale and magnitude. Being on the sea, within a thunderstorm, or encompassed by a mountain range, is sublime. It has nothing to do with harmonizing diversity. Akin to awe and wonder, these experiences do not stem from encounters with individuals but from nature's vastness and power as such. [3] Experience of the sublime, unmentioned by Dombrowski, is needed for an adequate discussion of the value of species and ecosystems. The neo-classical value theory he deploys here is not up to the job.

My last question concerns the role of God. Dombrowski might respond to my criticisms of his value theory by reminding me that the aesthetic argument is secondary. What really matters is the metaphysical and moral primacy of individual centers of experience. I have already argued that his meta- physics of individuality is confused and unscientific. But further, if there really is no ultimate conflict between what we owe individuals and what we owe the divine nature, I fail to see why there is any need for God at all.[4] Eternal preservation of value in God's mental museum would actually decrease the value of those experiences which derive poignancy from their finitude. Flowers that fade and die are precious in part for this very reason. Similarly, something with little value in the first place is hardly made more valuable by lasting longer.

Individual autonomy and divine authority have been in conflict ever since the Enlightenment. Speaking for myself, if I really believed I would live for eternity, much of the savor and motivation of my life would disappear. Inmortality would decrease the value of my life and the lives of individuals who think like me. So, if Dombrowski really wants to insist that the experience of individuals has ultimate worth, then my point is that the assumption that God preserves individual experiences forever is at best useless and at worst destructive of such finite individual values.

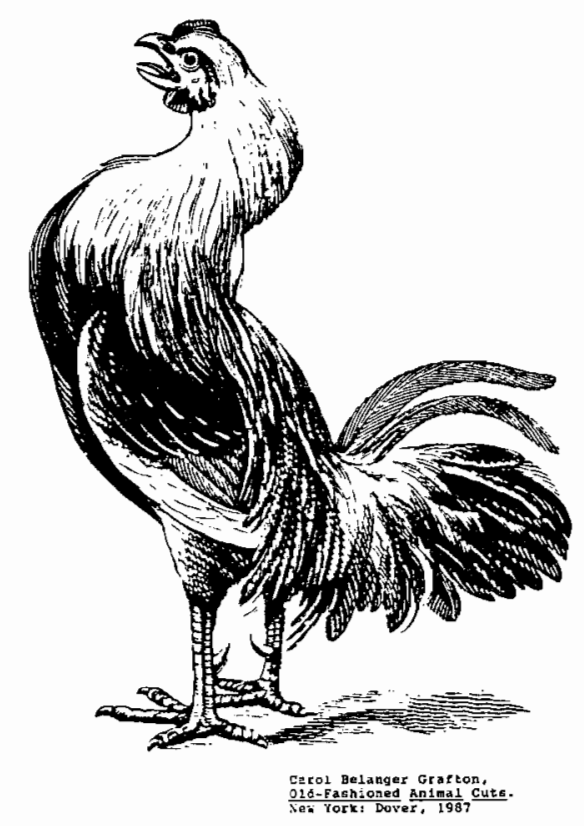

Notes

1. Daniel Dombrowski, The Philosophy of Vegetarianism (Amherst: University of Massachusetts Press, 1984): 133-4. 
2. A symptom of this is his confusion about the nature of a species. When Dombrowski says that the only way to extinguish a species is to kill its members, he is mistaken. A species with few members can be sterilized, and no killing need occur. The root of this mistake is to confuse a closed class, where all members are present at any given moment, with an open class, where new individuals may or may not be added later on. A species is an open class, not a closed one.
3. That we know ourselves more fully through encountering that which is larger and other than ourselves is a point given systematic metaphysical expression by Fichte, Hegel, Marx, and Sartre. There are extensive discussions of the sublime in eighteenth century aesthetic theories, such as Kant's Critique of Judgment.

4. Another mistake is that contrary to Dombrowski, not all religions postulate a God whose role it is to preserve value. Most Eastern religions do not do so.

\title{
A Creature Like A Chorus
}

\author{
All of man's \\ crashing of self-hatred and disdain \\ creates the vast \\ vacuum of his death: \\ all his whirling-dervish motion \\ of sick cupidity and annihilation \\ is the final silence and the cold quietude. \\ But into that -- piercing into that insensate void \\ of man's departure -- presses the choir \\ of some fresh species, the laughing and mellifluous \\ music of living throats \\ proclaiming again God's astonishment. \\ And what is this chorus, this wild harmony? \\ Some new enchanted animal \\ the human frenzy could not sweep away, drag with it \\ to extinction; some form of purer living \\ up-pouring from the resonance of earth; \\ a creature man could not imagine, \\ and so could not befoul; a straightness \\ flaming in values man reviled; a sounding \\ of innocent and generous symphonies \\ that nature hinted at \\ before the rack of mortal conflict \\ and ambition broke the bonds of galaxies, \\ severed the tendons of perceptible law. \\ The dying scientist \\ whose facts had plundered love, \\ whose predictability was the world's altar - \\ grew dumb. \\ The fist of human historical authority \\ shattered inaudibly under the pressure \\ of that newer atmosphere -- the extra-sensory beings \\ from mystic flying objects \\ scoffed at in those final days. \\ And here, here, at length, and for a long and prosperous span, \\ stands up this rolling beauty of fierce singing \\ this primitive and savagely moral animal \\ -- impetuous, affectionate - \\ man might have been.
}

George Abbe 